\title{
Behavioral observations and stable isotopes reveal high individual variation and little seasonal variation in sea otter diets in Southeast Alaska
}

\author{
Nicole L. LaRoche ${ }^{1, *}$, Sydney L. King ${ }^{2}$, Matthew C. Rogers ${ }^{3}$, Ginny L. Eckert ${ }^{1}$, \\ Heidi C. Pearson ${ }^{1,2}$ \\ ${ }^{1}$ College of Fisheries and Ocean Sciences, University of Alaska Fairbanks, 17101 Point Lena Loop Rd, Juneau, AK 99801, USA \\ ${ }^{2}$ Department of Natural Sciences, University of Alaska Southeast, 11066 Auke Lake Way, Juneau, AK 99801, USA \\ ${ }^{3}$ NOAA National Marine Fisheries Service, Alaska Fisheries Science Center, Auke Bay Laboratories, \\ 17109 Point Lena Loop Rd, Juneau, AK 99801, USA
}

\begin{abstract}
Two complementary approaches were used to assess year-round variation in the diet of sea otters Enhydra lutris around Prince of Wales Island (POW) in southern Southeast Alaska, a region characterized by mixed-bottom habitat. We observed sea otters foraging to determine diet composition during the spring and summer. Then, we obtained sea otter vibrissae, which record temporal foraging patterns as they grow, from subsistence hunters to identify year-round changes in sea otter diets via stable isotope analysis of carbon $\left(\delta^{13} \mathrm{C}\right)$ and nitrogen $\left(\delta^{15} \mathrm{~N}\right)$. We compared the stable isotopes from sea otter vibrissae and sea otter prey items that were collected during spring, summer, and winter. Overall, year-round sea otter diet estimates from stable isotope signatures and visual observations from spring and summer were dominated by clams in terms of biomass, with butter clams Saxidomus gigantea the most common clam species seen during visual observations. Our results indicate that these sea otters, when considered together at a regional level around POW, do not exhibit shifts in the main prey source by season or location. However, sea otter diets identified by stable isotopes had a strong individual-level variation. Behavioral variation among individual sea otters may be a primary driving factor in diet composition. This study provides quantitative diet composition data for modeling predictions of invertebrate population estimates that may aid in the future management of shellfisheries and subsistence hunting and the development of co-management strategies for this protected species.
\end{abstract}

KEY WORDS: Enhydra lutris $\cdot$ Foraging ecology $\cdot$ Marine mammal $\cdot$ Apex predator $\cdot{ }^{13} \mathrm{C} \cdot{ }^{15} \mathrm{~N}$

\section{INTRODUCTION}

The importance of sea otters Enhydra lutris in shaping nearshore marine ecosystems is well documented along the northeast Pacific coast (Estes \& Palmisano 1974, Hughes et al. 2013, Rechsteiner et al. 2019, Hale et al. 2019). Sea otters are keystone predators with voracious appetites capable of causing major ecological shifts in nearshore marine ecosystems (Estes et al. 2016). Unlike most marine mammals, sea otters lack blubber for warmth. Instead, sea otters maintain very

${ }^{*}$ Corresponding author: nlaroche@alaska.edu high metabolic rates, resulting in the need to consume $19-39 \%$ of their body weight in food per day, dependent on reproductive status (Costa 1982, Davis 2020). Sea otter predation can control populations of sea urchins Strongylocentrotus spp. in rocky habitats, relieving grazing pressure on kelps. Decreased grazing increases kelp cover, which in turn provides habitat for juvenile fishes and invertebrates (Estes \& Palmisano 1974, Estes \& Duggins 1995). Trophic cascades have also been documented in seagrass communities, where sea otter presence is positively corre-

() The authors 2021. Open Access under Creative Commons by Attribution Licence. Use, distribution and reproduction are unrestricted. Authors and original publication must be credited. 
lated with eelgrass Zostera marina biomass (Raymond et al. 2021, Hughes et al. 2013).

Sea otter recolonization patterns impact nearshore ecosystems (Estes \& Duggins 1995). Sea otters once inhabited nearshore Pacific Ocean ecosystems from Japan to Baja California. However, due to hunting for lucrative fur markets in Russia and China, by the late 19th century, only 11 populations remained of the once-continuous distribution. In 1911, sea otter hunting was prohibited by the International Fur Seal Treaty (Burris \& McKnight 1973). The nearshore ecosystem lacked a keystone predator while sea otters were absent, allowing commercially valuable species such as geoduck clams Panopea generosa, red sea urchins Mesocentrotus franciscanus, Dungeness crabs Metacarcinus magister, and sea cucumbers Apostichopus californicus to flourish (Pritchett \& Hoyt 2008, Larson et al. 2013, Hoyt 2015). In Southeast Alaska, the Alaska Department of Fish and Game and the US Atomic Energy Commission initiated a translocation program to restore sea otters to their historical range. In total, about 400 sea otters were relocated to 6 locations in Southeast Alaska in the 1960s (Burris \& McKnight 1973, Jameson et al. 1982). Since then, sea otter range and abundance in Southeast Alaska have increased. Aerial counts estimated that approximately 25000 sea otters were present in Southeast Alaska in 2011, and very few locations within Southeast Alaska were estimated to be at carrying capacity at the time of that survey (Tinker et al. 2019).

Length of time since recolonization in Southeast Alaska plays an important role in sea otter diet diversity (Hoyt 2015). At newly recolonized sites, sea otters consume fewer species as compared to sites where sea otters have been present for more extended periods of time. Sea otters in a newly colonized rocky habitat consume red sea urchins at very high rates before moving on to smaller, less calorically rich prey sources (e.g. sea cucumbers). As sea otter populations increase and reach carrying capacity, overall prey diversity increases (Hoyt 2015).

Although time since recolonization affects sea otter diets at a population level (Hoyt 2015), sea otters often exhibit diet variations on an individual level (Tinker et al. 2008). In regions of California where sea otters are at or near carrying capacity, sea otters often specialize on a small subgroup of prey items (Estes et al. 2003, Tinker et al. 2008, Newsome et al. 2009). Sea otter individuality is also evident in rocky substrate habitats where populations are at carrying capacity. However, to date, studies of sea otters in mixed and soft sediment habitats have not revealed prey specialization among individuals, partially due to the need to group prey to family or higher classes (Newsome et al. 2015).

Year-round studies of diet are important for understanding the foraging ecology of sea otters and their ecosystem roles. Populations at or near carrying capacity off California show that diet remains consistent over seasons but can vary at an individual level (Oftedal et al. 2007, Tinker et al. 2008, Newsome et al. 2009). In areas with rugged terrain and harsh weather conditions, such as Alaskan coastlines, year-round visual observations are difficult. Northern latitudes also face a lack of daylight hours in the winter months. Due to these restrictions, studies of sea otter diets in Alaska have typically occurred from April to October (Weitzman 2013, Larson et al. 2013, Coletti et al. 2014, Hoyt 2015). Alternative methods are needed to examine diet on a year-round basis in regions such as Alaska and to complement the current state of knowledge of sea otter diet.

Stable isotopes are a common tool for assessing diet composition in ecological studies, and can be obtained from a range of soft and hard tissues (e.g. blood, muscle, hair) (Fry 2006, Crawford et al. 2008, Newsome et al. 2010, Wild et al. 2020). As compared to visual observations, stable isotopes can (1) provide temporally integrated estimates of prey contributions with lower cost and field effort, (2) be used in situations where field observations are impossible (e.g. no access roads or poor weather conditions), (3) detect cryptic foraging patterns due to factors such as small prey size and offshore ranging patterns, and (4) provide a measure of assimilated diet as opposed to the ingested diet. In ecological studies, nitrogen and carbon stable isotopes are commonly used in the analysis of food web structure (Fry 2006). Nitrogen isotope ratios $\left(\delta^{15} \mathrm{~N}\right)$ can determine a species' relative trophic level within a food web, as heavier nitrogen $\left({ }^{15} \mathrm{~N}\right)$ accumulates in an organism relative to its prey (Robinson 2001). Carbon isotope values $\left(\delta^{13} \mathrm{C}\right)$ can aid in identifying the original carbon source at sequestration, that is, the primary producer at the base of the food web. In marine systems, heavier carbon $\left({ }^{13} \mathrm{C}\right)$ accumulates more in benthic primary producers, such as kelp, whereas carbon in pelagic ecosystems where phytoplankton forms the base of the food web have less ${ }^{13} \mathrm{C}$ accumulation (Bell et al. 2016). In the nearshore marine system of which sea otters are a part, filter feeders, such as clams and mussels, exhibit pelagic signals, and kelp grazers, such as sea urchins, snails, and sea cucumbers, exhibit benthic signals (Bell et al. 2016).

To investigate seasonal variation in diet, keratinous tissues can be used as an isotopic record (Newsome et 
al. 2010, Cardona et al. 2017, Chilvers 2019). Vibrissae, the whiskers that grow on the base of the muzzle of sea otters, record temporal foraging patterns as they grow via changes in carbon and nitrogen isotopic signatures $\left(\delta^{13} \mathrm{C}\right.$ and $\left.\delta^{15} \mathrm{~N}\right)$. The root of the vibrissa, closest to the muzzle, carries the most recent dietary signature. Growth rates for marine mammal vibrissae have been studied in captive settings, allowing for standard rates to be applied to wild populations (Tyrrell et al. 2013, Beltran et al. 2016). Vibrissae in adult sea otters show consistent growth of approximately $7.7 \mathrm{~cm} \mathrm{yr}^{-1}$ (Tyrrell et al. 2013). Serial samples along a single vibrissa can thus show dietary shifts for an individual over time as the vibrissa grows.

According to traditional ecological knowledge on Prince of Wales Island (POW), Southeast Alaska, sea otters change their locations and diet during the winter months. However, due to the aforementioned challenges in conducting year-round foraging observations in Alaska, the exact nature of these dietary changes is unknown. Our over-arching question was to determine if there is seasonal and individual variation in sea otter diet and foraging locations around POW. We tested the following hypotheses: (1) visual foraging observations and stable isotope analysis provide similar estimates of sea otter diet, (2) sea otter diet varies by season and sea otter location, and (3) sea otter individuality in diet is apparent from stable isotope analysis. A year-round diet profile for sea otters of the POW region will provide a more comprehensive understanding of the interactions between sea otters and their shellfish prey.

\section{MATERIALS AND METHODS}

\subsection{Study site}

To assess sea otter diet, we concentrated studies around the western side of POW and the surrounding islands (Fig. 1). This region is within the Southeast

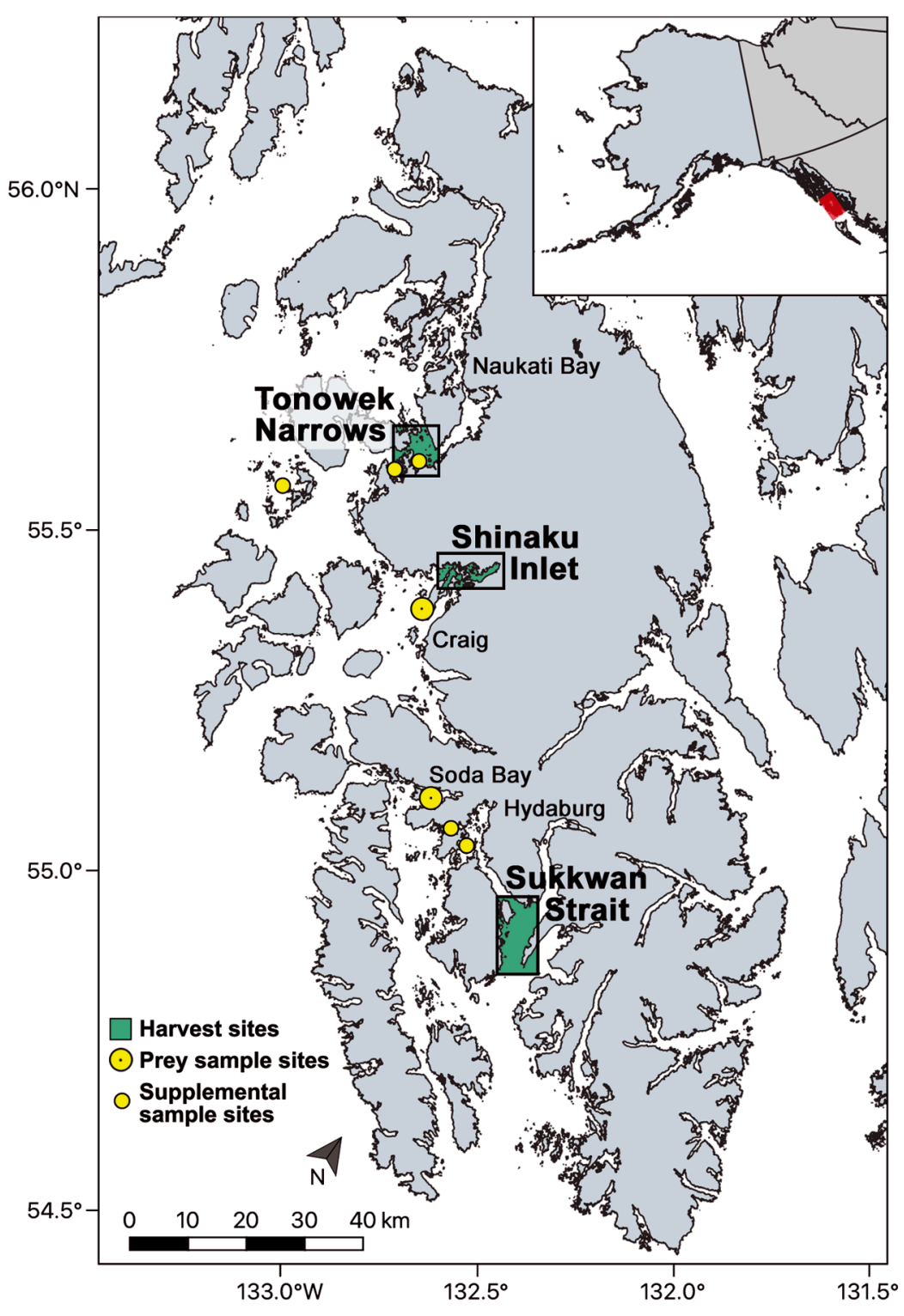

Fig. 1. Prince of Wales Island, Southeast Alaska. Yellow circles indicate invertebrate sampling sites and green boxes indicate where vibrissae were collected from harvested sea otters

Alaska population of sea otters. POW is an ideal study region because there are previous sea otter foraging studies upon which to build (Kvitek et al. 1993, Larson et al. 2013, Hoyt 2015). POW also contains 2 original sea otter translocation sites (Burris \& McKnight 1973, Jameson et al. 1982), creating a natural gradient for assessing changes in the sea otter diet due to recolonization patterns. The sea otter population that resides in the POW region is currently estimated to be below carrying capacity, with a few small sub-regions reaching carrying capacity (Tinker et al. 2019). 


\subsection{Visual foraging observations}

Sea otter foraging data were collected from May to August 2018 via visual observations. Data were collected from locations spanning the west coast of POW, encompassing soft and rocky habitats where sea otters occur in high densities (Fig. 1). Foraging observations were made from shore to assess sea otter diet composition using standardized methods (Dean et al. 2002). In brief, we followed individual sea otters using Questar telescopes (20-50x) for one foraging bout, defined as sequential dives by one sea otter for a maximum of 20 dives or until the sea otter was lost by the observer. A maximum of 20 dives was used to prevent bias arising from oversampling individuals that are easier to observe and undersampling individuals that are more difficult to observe. Further, 20 dives per bout has been shown to provide a significant relationship between prey type and diving success (D. Monson unpubl. data). Two trained observers conducted observations. For each surface interval (i.e. the time between 2 consecutive foraging dives), the observer recorded the prey item to species level when possible (Calkins 1978). Visual observations were separated into spring (6 May-20 June) and summer (21 June-13 August).

\subsection{Stable isotopes of sea otter prey}

The most commonly reported sea otter prey species from diet observations in other regions of Alaska (Anthony 1995, Oftedal et al. 2007, Weitzman 2013, Coletti et al. 2014, Hoyt 2015, Cartagena da Silva Matos 2016, Brown et al. 2019) were collected for stable isotope analysis. Prey species were grouped into functional prey groups (to genus or family), consisting of clams, crabs, sea cucumbers, snails, sea urchins, and mussels (Table 1). Potential prey items were collected at 2 sites around POW at 3 different time periods (May 2018, August 2018, and February 2019) to reflect possible geographic and temporal isotopic variation in the region. Site $1\left(55.532^{\circ} \mathrm{N}\right.$, $\left.133.147^{\circ} \mathrm{W}\right)$ was near the town of Craig, $\mathrm{AK}$, USA. Site $2\left(55.268^{\circ} \mathrm{N}, 133.003^{\circ} \mathrm{W}\right)$ was in Soda Bay, AK, USA (Fig. 1). All sampling was conducted in the intertidal zone at low tide by digging (for clams), deployment of Fukui minnow and crab traps (for crabs), or by hand while snorkel-

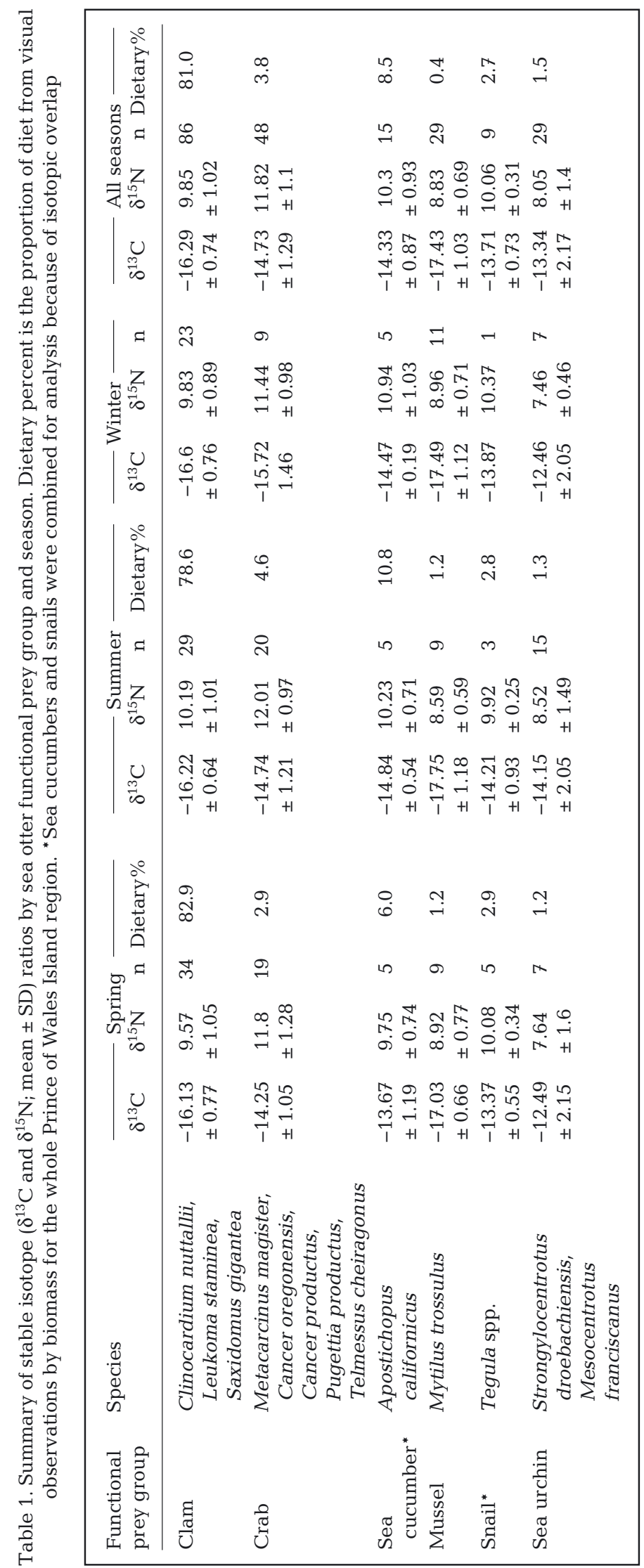


ing (for all other species). Five replicates per species were collected or as many as possible if 5 replicates were not present. There was no restriction on size of species collected. Occasionally, sea otter prey species were not present at either site. In such cases, those prey species were collected opportunistically at nearby sites to meet the target of 5 replicates (Table S1 in the Supplement at www.int-res.com/articles/suppl/ m677p219_supp.pdf). When prey items were collected outside of the main sites, mussels Mytilus trossulus were also collected for baseline isotopic comparison as they are prevalent across POW and are filter feeders (i.e. a primary consumer).

After collection, samples were cleaned with fresh tap water to remove sediment and debris and then frozen at $-20^{\circ} \mathrm{C}$ until analysis. For analysis, samples were thawed and separated into soft tissues and hard parts. We removed all hard parts to remove their influence on carbon values during stable isotope analysis. The soft tissues were weighed and homogenized in a food processor (Cuisinart Mini-prep). Samples were then dried in a LECO Thermogravimetric Analyzer 701 (TGA) dryer at $135^{\circ} \mathrm{C}$ or in a gravity convection oven (VWR Symphony $414004-552$ ) at $70^{\circ} \mathrm{C}$.

\subsection{Stable isotopes of sea otter vibrissae}

Sea otter vibrissae were collected through the US Fish and Wildlife Service (USFWS) tagging program associated with subsistence harvest. Per the Marine Mammal Protection Act (Marine Mammal Commission 2018), Alaska Natives living in coastal Alaskan communities can legally harvest sea otters. Hunters report all takes with the USFWS through the sea otter tagging program enacted by the Marine Mammal Protection Act of 1972 (16 U.S.C. 1379). Each harvested sea otter received a tag that contains information on harvest date, location, sex, age (if known), and group size. We worked with hunters and taggers on POW who collected and submitted vibrissae to the USFWS as part of their standard harvest protocol. Forty-five adult sea otters harvested by subsistence hunters from July to October 2019 were included in this study. Between 1 and 3 vibrissae with root included were plucked from the base of the muzzle of each harvested sea otter. Previous research has shown that a sample size of $>10$ sea otters per region is ideal for assessing regional-level diet composition using carbon and nitrogen stable isotopes (Elliott Smith et al. 2015).

In the laboratory, sea otter vibrissae were cleaned with $70 \%$ ethanol, taped down, and marked every
$0.7 \mathrm{~cm}$ (Fig. 2) to represent 1 mo of growth based on a captive study (Tyrrell et al. 2013). Depending on individual vibrissa length, there were 5 to 14 samples per vibrissa. In each marked subsection, approximately a $0.4 \mathrm{mg}$ was cut and weighed using a Sartorius MC210S balance (Sartorius AG) and then sealed into a tin capsule $(3.3 \times 5 \mathrm{~mm})$. Each sea otter vibrissa was measured after subsections were made, and based on the length from the root and date collected, were grouped into seasons according to the known growth estimate of $7.7 \mathrm{~cm} \mathrm{yr}^{-1}$ for adult sea otters (Tyrrell et al. 2013). Subsections were assigned seasons for spring (21 March-20 June), summer (21 June20 September), fall (21 September-20 December), and winter (21 December-20 March).

\subsection{Stable isotope analysis}

All tissue samples (i.e. prey and vibrissae) were analyzed for carbon $\left(\delta^{13} C\right)$ and nitrogen $\left(\delta^{15} N\right)$ stable isotope ratios at Auke Bay Laboratory, Recruitment Energetics and Coastal Assessment Chemistry Laboratory (Juneau, AK, USA). We used a FlashSmart elemental analyzer coupled to a Delta-V continuousflow isotope ratio mass spectrometer (Thermo Fisher Scientific). We report stable isotope ratios in per mil

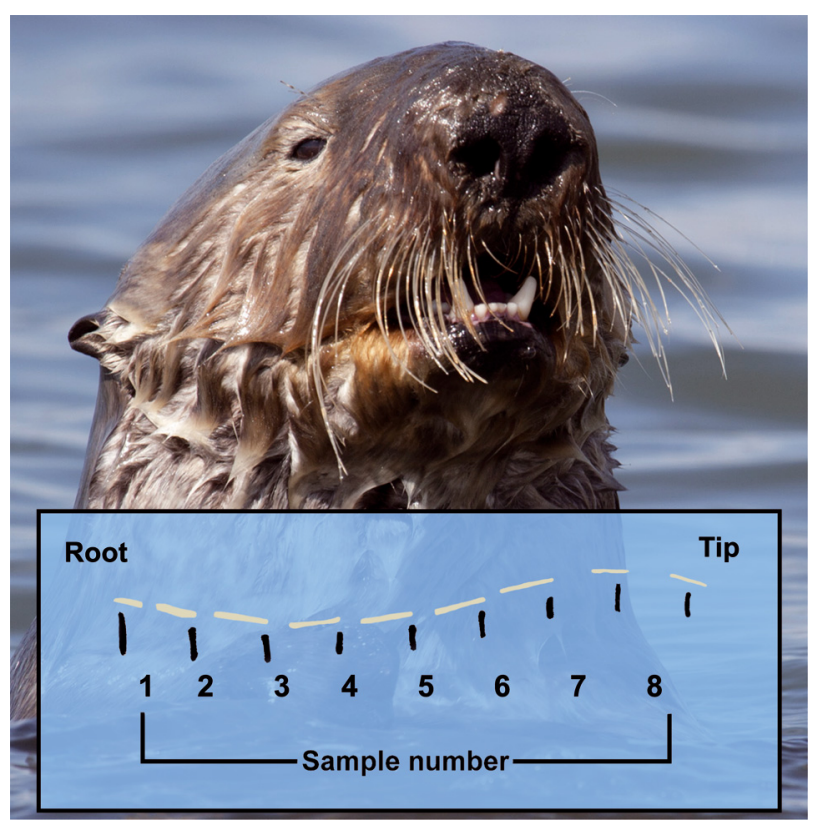

Fig. 2. Sea otter vibrissa with subsections removed for sampling. Each vibrissa was taped down in $0.7 \mathrm{~cm}$ increments (representing approximately 1 mo of growth) marked with a line. Samples were taken from each sub-section (labeled as sample number) and then the length from the root was measured after all cuts were made to estimate the season based on sea otter harvest date and growth estimates 
$(\%)$ using the delta $(\delta)$ notation. Isotope ratios are reported relative to Vienna-Pee Dee Belemnite for carbon and air for nitrogen. Replicated measurements of internal laboratory standards (purified methionine, homogenized Chinook salmon Oncorhynchus tshawytscha muscle and homogenized pollock Gadus chalcogrammus muscle) were used as quality controls (standard deviation of \pm 0.10 for $\delta^{13} \mathrm{C}$ and \pm 0.15 for $\delta^{15} \mathrm{~N}$ ). We measured the C:N ratio for each subsample to control for the quality of vibrissae protein (Ambrose 1990). Samples with a C:N ratio outside the long-term average and $95 \%$ confidence interval $(\mathrm{n}=319)$ of $2.79 \pm 0.25$ were re-analyzed. Sea otter prey tissue samples were corrected for lipid-rich samples that were higher than 3.5:1 C:N, with the following equation (Post et al. 2007):

$$
\delta^{13} \mathrm{C}_{\text {normalized }}=\delta^{13} \mathrm{C}_{\text {untreated }}-3.32+0.99 \times \mathrm{C}: \mathrm{N}
$$

Trophic discrimination factors (TDFs) are used to correct for isotopic differences between a consumer and its prey. On average, a TDF of $\sim 1.0-2.5 \%$ for $\delta^{13} \mathrm{C}$ and $\sim 2.0-3.5 \%$ for $\delta^{15} \mathrm{~N}$ is one trophic step up the food web from source to consumer (Post 2002, Sponheimer et al. 2003, Caut et al. 2009). As a consumer changes its diet and feeds up the food web, correlations between $\delta^{13} \mathrm{C}$ and $\delta^{15} \mathrm{~N}$ are typically strong, positive correlations because of the tropic discrimination (Cardona et al. 2017). Estimating TDF depends on individual metabolic needs and the prey consumed. Because we did not do a direct test of TDFs in this study, TDFs of $2.0 \%$ for $\delta^{13} \mathrm{C}$ and $2.8 \%$ for $\delta^{15} \mathrm{~N}$ were chosen based on similarity to other marine mammal studies using keratinous tissues (Lesage et al. 2002, Caut et al. 2009, Wolf et al. 2009, Newsome et al. 2010, Beltran et al. 2016). Error is incorporated into the mixing model to compensate for unknown metabolic variations in sea otters and invertebrate prey.

\subsection{Statistical analyses}

We calculated the caloric intake for sea otters based on visual foraging observations using the Sea Otter Foraging Analysis (SOFA) program, which is based in Matlab (MathWorks) and maintained by the USGS Alaska Science Center in Anchorage, AK, USA. SOFA uses a Monte Carlo-based simulation to account for unknown prey items and potential sample bias. SOFA is a Bayesian model, with estimated biomass for individual prey types across the spring and summer months. All SOFA outputs are reported as means with standard deviation (Tinker et al. 2008).
To test seasonal variation in sea otter diet, a Bayesian mixing model was run in R v. 4.0.0 (R Core Team 2020) using the program MixSIAR (Stock \& Semmens 2016). For each functional prey group, we estimated the mean proportional contribution by season at the sea otter regional level. We combined sites for the mixing model, as we had small sample sizes for certain species (i.e. sea cucumbers and snails). We tested mixing model sensitivity across prey collected in every season by running separate models for each season in which prey were collected (Fig. S2). There were no significant changes in the mixing model outputs, so we combined all seasons. Mixing models were created for each harvest site, using season as a fixed factor and an informed prior from proportional diet estimates. Posterior probabilities were estimated using 3 chains of length 1000000 after a burn-in of 50000 iterations, and chains were thinned by subsampling every 500th iteration. Each site was run separately, with an approximately $50 \mathrm{~h}$ run time. Sea cucumbers and snails were combined in stable isotope analyses because their mean and standard deviation for $\delta^{13} \mathrm{C}$ and $\delta^{15} \mathrm{~N}$ overlapped and were isotopically indistinguishable.

To test seasonal variation in sea otter diet around POW, we created a linear mixed-effects (LME) model with an ANOVA for each sea otter harvest site's $\delta^{13} \mathrm{C}$ and $\delta^{15} \mathrm{~N}$ values, with season as a fixed effect and sea otter ID as a random effect to account for the multiple sub-samples for each vibrissa $(\alpha=0.05)$. An LME was used because the data did not fit a normal curve. No transformations were needed for the model. Post hoc comparisons to determine pairwise differences between seasons were conducted with a Tukey's procedure. We ran all statistical analyses in $\mathrm{R}$ v. 4.0.0 (R Core Team 2020) with the packages nlme (Pinheiro et al. 2020), emmeans (Lenth 2019), and MuMIn (Bartoń 2019).

To test for individuality across the POW region, we calculated a Pearson's correlation of serial $\delta^{13} \mathrm{C}$ and $\delta^{15} \mathrm{~N}$ values for each individual using $\mathrm{R}$ v. 4.0.0 (R Core Team 2020). All data sets are archived in a publicly accessible database with the Knowledge Network for Biocomplexity (LaRoche \& Rogers 2020, LaRoche et al. 2020).

\section{RESULTS}

\subsection{Visual foraging observations}

Between 6 May and 13 August 2018, we recorded 3385 foraging dives from 362 sea otter foraging bouts. 
Foraging bouts were evenly distributed around the western side of POW. Sea otters were observed to consume a total of 44 invertebrate taxa (to species, when possible) (LaRoche 2020). The most frequently consumed functional prey group across spring and summer was clams $(82.9 \%$ in spring, $78.6 \%$ in summer), followed by sea cucumbers ( $6.0 \%$ in spring, $10.8 \%$ in summer), crabs $(2.9 \%$ in spring, $4.6 \%$ in summer), snails (2.9\% in spring and $1.6 \%$ in summer), sea urchins $(1.2 \%$ in spring and $2.2 \%$ in summer), and mussels $(1.2 \%$ in spring and $0.2 \%$ in summer) (Table 1). Because it was not possible to track individuals, statistical differences could not be determined between diet during the spring and summer months. Within the clam group, the butter clam Saxidomus gigantea was the most frequently consumed species.
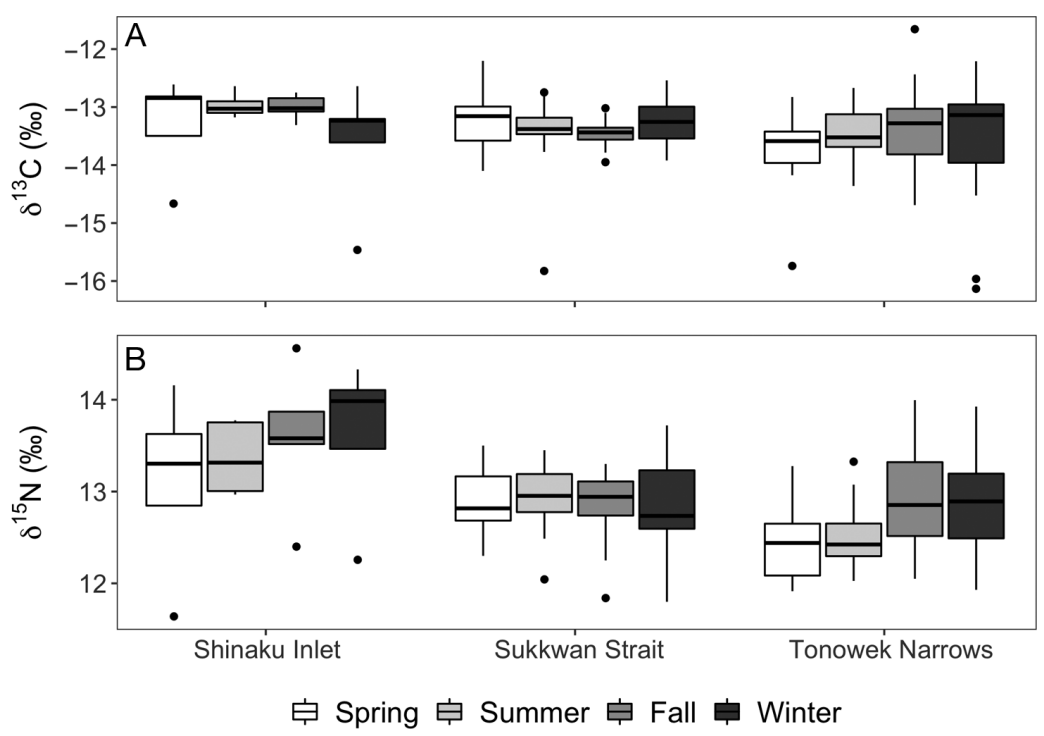

Fig. 3. Sea otter vibrissae stable isotope ratios (A) $\delta^{13} \mathrm{C}$ and (B) $\delta^{15} \mathrm{~N}$ by harvest site and season. Seasons were estimated from vibrissae growth rate $(7.7 \mathrm{~cm}$ $\mathrm{yr}^{-1}$ ) and sample distance from the root. Box represents $50 \%$ of the data with the horizontal line at the median and the whiskers showing $95 \%$ of the data. Points in black are outside of the $95 \%$ confidence interval. Shinaku Inlet, $\mathrm{n}=$ 5; Sukkwan Strait, $\mathrm{n}=16$; Tonowek Narrows, $\mathrm{n}=24$

\subsection{Stable isotopes of sea otter prey}

For each functional prey group, $\delta^{13} \mathrm{C}$ and $\delta^{15} \mathrm{~N}$ values were compared by site and season and did not have uniform variations across sites (Table 1). Filter feeders, including clams and mussels, had higher $\delta^{13} \mathrm{C}$ and $\delta^{15} \mathrm{~N}$ values in Craig than in Soda Bay for all seasons, but this pattern was not seen in higher-level consumers or sea urchins (Fig. S1 in the Supplement). Sea otter prey values varied from a previous study in other regions, where $\delta^{15} \mathrm{~N}$ had elevated values and $\delta^{13} \mathrm{C}$ had lower values for all prey types compared to the present study (Newsome et al. 2009).

\subsection{Stable isotopes of sea otter vibrissae}

Across all harvest locations, mean sea otter vibrissae $\delta^{13} \mathrm{C}$ values ranged from -15.54 to $-12.46 \%$ and mean $\delta^{15} \mathrm{~N}$ values ranged from 12.15 to $14.20 \%$ (Fig. 3 and Table S2 in the Supplement). Sea otter $\delta^{13} \mathrm{C}$ values significantly varied by season within each harvest site (Tonowek Narrows, $F_{3,23}=3.05, \mathrm{p}=$ 0.03; Shinaku Inlet, $F_{3,4}=3.60, \mathrm{p}=0.02$; Sukkwan Strait, $F_{3,15}=3.36, \mathrm{p}=0.02$ ). Sea otter $\delta^{15} \mathrm{~N}$ values significantly varied by season within the Tonowek Narrows harvest site $\left(F_{3,23}=18.98, \mathrm{p}<0.0001\right)$ but not the other 2 harvest sites (Table 2). LME models for each isotope and harvest site suggested that seasonal variability $\left(\mathrm{R}_{\mathrm{m}}^{2}\right)$ accounted for 1 to $14 \%$ of the total variability in isotope values and the remaining variability was split between sea otters $\left(\sigma_{b}\right)$ and within a sea otter $\left(\sigma_{\mathrm{e}}\right)$.

Isotopic information obtained from sea otter vibrissae were within the range of the sea otter prey isospace (Fig. 4), which indicates that mixing models can be used to assess sea otter diets in this region. This also indicates that the prey isotopic signatures and TDFs are appropriate for the individuals in this study.

Across all vibrissae, the mean variation of $\delta^{13} \mathrm{C}$ and $\delta^{15} \mathrm{~N}$ across individual vibrissae was $1.43 \%$ and $1.29 \%$, respectively, indicating little variation at the regional level. However, at the individual level, distinct patterns emerged (Fig. 5). The highest variation of $\delta^{13} \mathrm{C}$ and $\delta^{15} \mathrm{~N}$ occurred in sea otter 521, which had a change in $\delta^{13} \mathrm{C}$ of $3.95 \%$ and change in $\delta^{15} \mathrm{~N}$ of $2.51 \%$ (Fig. 5B). The relationship between $\delta^{13} \mathrm{C}$ and $\delta^{15} \mathrm{~N}$ in sea otter vibrissae, as determined by Pearson's correlation, varied among individuals, from highly negative $(r=-0.77, p=0.025$, sea otter 752; Fig. 5C) to highly positive $(r=0.97, \mathrm{p}<0.001$, sea otter 287; Fig. 5D). Thirty-four sea otters (75\%) had a positive correlation between $\delta^{13} \mathrm{C}$ and $\delta^{15} \mathrm{~N}$ in the vibrissae, and 11 sea otters ( $25 \%$ ) had a negative cor- 
Table 2. Tukey's non-additivity pairwise comparisons for each season with $\delta^{13} \mathrm{C}$ and $\delta^{15} \mathrm{~N}$ values separated for each site. $\mathrm{R}_{\mathrm{m}}^{2}$ is the marginal coefficient of determination, $\sigma_{\mathrm{b}}$ is the standard deviation, and $\sigma_{\mathrm{e}}$ is the residual standard deviation for each site model. Significant values $(\mathrm{p}<0.05)$ are in bold

\begin{tabular}{|c|c|c|c|c|c|c|c|c|c|c|}
\hline \multirow[t]{2}{*}{ Site } & \multicolumn{2}{|c|}{ Pairwise season (n) } & \multicolumn{4}{|c|}{$-\delta^{13} \mathrm{C}$} & \multicolumn{4}{|c|}{$-\delta^{15} \mathrm{~N}$} \\
\hline & & & & & & & & & & $v_{\mathrm{e}}$ \\
\hline \multirow{6}{*}{$\begin{array}{c}\text { Tonowek } \\
\text { Narrows }\end{array}$} & Spring (57) & Summer (53) & 0.10 & \multirow[t]{6}{*}{0.02} & \multirow[t]{6}{*}{0.62} & \multirow[t]{6}{*}{0.49} & 0.87 & \multirow[t]{6}{*}{0.14} & \multirow[t]{6}{*}{0.30} & \multirow[t]{6}{*}{0.42} \\
\hline & Spring (57) & Fall (58) & 0.02 & & & & $<0.0001$ & & & \\
\hline & Spring (57) & Winter (67) & 0.30 & & & & $<0.0001$ & & & \\
\hline & Summer (53) & Fall (58) & 0.95 & & & & $<0.0001$ & & & \\
\hline & Summer (53) & Winter (67) & 0.91 & & & & 0.0001 & & & \\
\hline & Fall (58) & Winter (67) & 0.60 & & & & 0.78 & & & \\
\hline \multirow{6}{*}{$\begin{array}{l}\text { Shinaku } \\
\text { Inlet }\end{array}$} & Spring (14) & Summer (15) & 0.65 & \multirow[t]{6}{*}{0.12} & \multirow[t]{6}{*}{0.45} & \multirow[t]{6}{*}{0.66} & 0.35 & \multirow[t]{6}{*}{0.04} & \multirow[t]{6}{*}{0.39} & \multirow[t]{6}{*}{0.41} \\
\hline & Spring (14) & Fall (22) & 0.76 & & & & 0.15 & & & \\
\hline & Spring (14) & Winter (11) & 0.26 & & & & 0.15 & & & \\
\hline & Summer (15) & Fall (22) & 1.00 & & & & 0.95 & & & \\
\hline & Summer (15) & Winter (11) & 0.02 & & & & 0.93 & & & \\
\hline & Fall (22) & Winter (11) & 0.04 & & & & 1.00 & & & \\
\hline \multirow{6}{*}{$\begin{array}{l}\text { Sukkwan } \\
\text { Strait }\end{array}$} & Spring (43) & Summer (47) & 0.04 & \multirow[t]{6}{*}{0.04} & \multirow[t]{6}{*}{0.39} & \multirow[t]{6}{*}{0.41} & 0.88 & \multirow[t]{6}{*}{0.01} & \multirow[t]{6}{*}{0.25} & \multirow[t]{6}{*}{0.35} \\
\hline & Spring (43) & Fall (22) & 0.26 & & & & 1.00 & & & \\
\hline & Spring (43) & Winter (20) & 1.00 & & & & 0.78 & & & \\
\hline & Summer (47) & Fall (22) & 0.99 & & & & 0.94 & & & \\
\hline & Summer (47) & Winter (20) & 0.12 & & & & 0.43 & & & \\
\hline & Fall (22) & Winter (20) & 0.34 & & & & 0.83 & & & \\
\hline
\end{tabular}

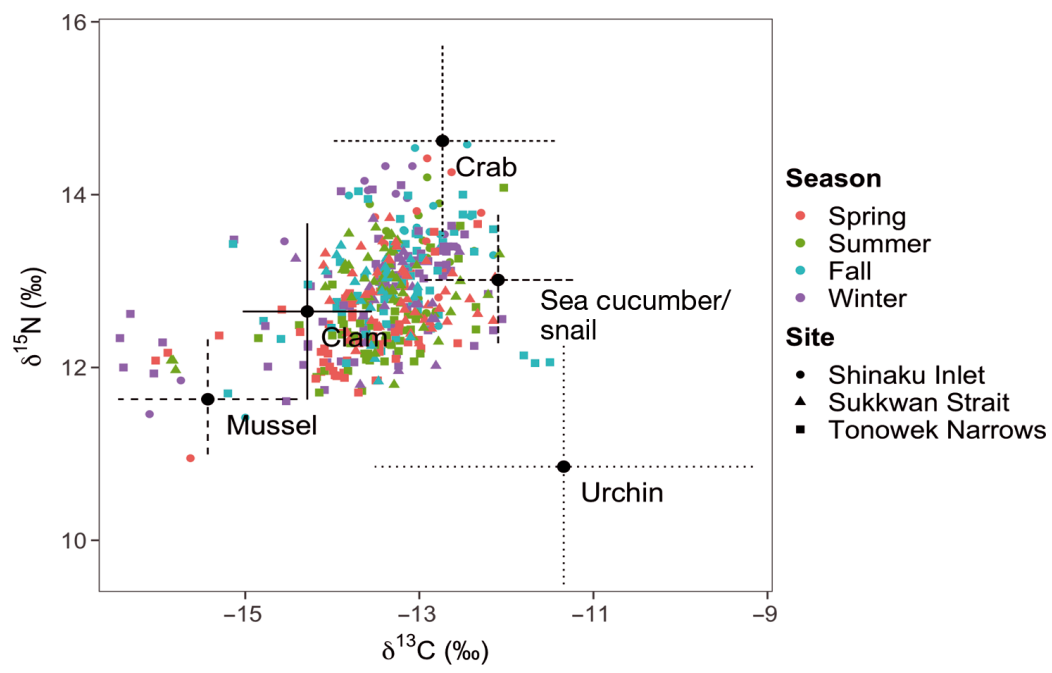

Fig. 4. Stable isotope ratios $\delta^{13} \mathrm{C}$ and $\delta^{15} \mathrm{~N}$ of sea otters (as determined by vibrissae) and their prey (means $\pm \mathrm{SD}$ ). Sea otter prey values were corrected for trophic discrimination by subtracting $2.0 \%$ and $2.8 \%$ from carbon and nitrogen isotope values, respectively. Each season was derived from estimated growth rates of sea otter vibrissae and sample distance from the root. Site indicates where the sea otter was harvested

\subsection{Mixing model results}

Each site exhibited seasonal variation in diet (Fig. 6). Clams comprised the largest proportion of the diet during every season, but the overall estimates of diet composition were variable, with coefficients of variation ranging from 0.06 to 0.25 . The range in coefficients of variation reflects a high degree of variability in the diet and a high degree of uncertainty in the model. Seasonal variation was most apparent at the Shinaku Inlet site, where the mean proportion of clams in sea otter diets ranged from 40 to $78 \%$ across seasons, but the sample size at this site was lower than the other 2 sites. Diet proportions during fall exhibited little inter-site variation.

\section{DISCUSSION}

relation (Table S2 in the Supplement). Sea otter vibrissae stable isotope values were similar to those of sea otters in soft and mixed sediment in previous studies (Newsome et al. 2009, 2015, Mandi 2020). Mean $\delta^{13} \mathrm{C}$ and $\delta^{15} \mathrm{~N}$ values for this study had lower standard deviations than studies that had rocky sediment (Newsome et al. 2009, 2015).
Analysis of stable isotopes from sea otter vibrissae in Southeast Alaska gave insight into year-round diets of sea otters around POW, information challenging to obtain from visual observations. The yearround diet estimates from stable isotopes suggest that diets have slight site and seasonal variations and 
520

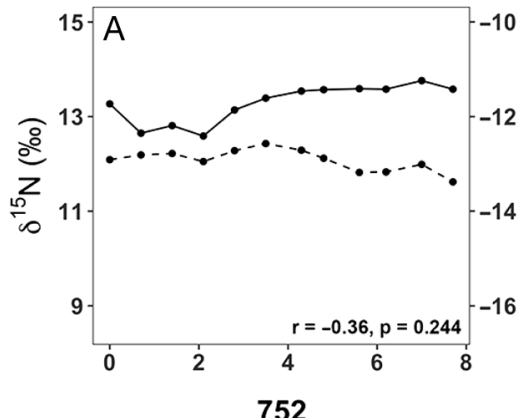

752

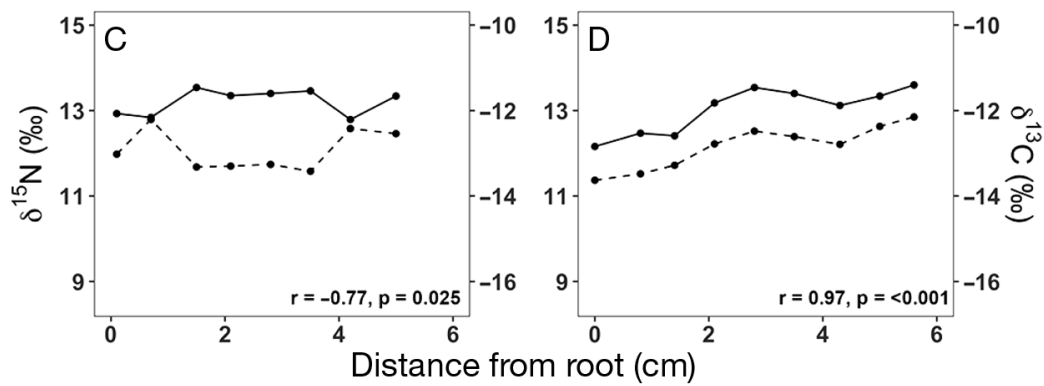

Fig. 5. Stable isotope ratios $\delta^{15} \mathrm{~N}$ (solid line, left $y$-axis) and $\delta^{13} \mathrm{C}$ (dotted line, right $y$-axis) for 4 sea otter vibrissae from root to tip, with a maximum length of $8 \mathrm{~cm}$. (A) Individual 520 (from Shinaku Inlet) has little temporal variation in either carbon or nitrogen ratios, with a non-significant negative correlation. (B) Individual 521 (from Shinaku Inlet) shows a high temporal variation in both carbon and nitrogen, which are positively correlated. (C) Individual 752 (from Sukkwan Strait) has a significant negative correlation between carbon and nitrogen. (D) Individual 287 (from Tonowek Narrows) demonstrates increases in stable isotope ratios over the length of the vibrissa, with a high correlation between carbon and nitrogen

were similar to the diet compositions determined by visual observations in summer months. Compared to visual foraging observations, there was greater variation in sea otter diet estimates from stable isotope analysis. Clams were the dominant prey using visual and isotopic methods across all sites and seasons. Supplemental prey items, in contrast, varied in the diet composition across sites and seasons. Only one sea otter showed a change in carbon and nitrogen isotope ratios large enough to represent a trophic level shift or a change in food web source. This is in contrast to a previous study in rocky substrate, where $23 \%$ of sea otters had $>2 \%$ variation in $\delta^{13} \mathrm{C}$ or $\delta^{15} \mathrm{~N}$ (Newsome et al. 2009). Although most sea otters did not appear to exhibit large dietary shifts, there was strong individual-level variation in vibrissae stable isotope values, which suggests that some individuals may vary their diet seasonally and that sea otter behavior is an important factor driving sea otter diet composition. However, because this study did not utilize tagged individuals, it was not possible to differentiate potential diet changes due to sea otter movement versus prey items.

\subsection{Seasonal variation}

\subsubsection{Seasonal patterns throughout POW}

We collected prey throughout the year to account for seasonal variation in prey stable isotopes. Differences in $\delta^{13} \mathrm{C}$ and $\delta^{15} \mathrm{~N}$ across seasons were not consistent for all prey species. Filter-feeding bivalves (mussels and clams) expressed minimal isotopic variation across seasons; however, mobile animals such as crabs, sea cucumbers, snails, and sea urchins showed greater seasonal variation in both $\delta^{13} \mathrm{C}$ and $\delta^{15} \mathrm{~N}$. Sessile invertebrate (clams and mussels) seasonal variability is dependent largely on the environmental changes such as additional freshwater input with snow melt in the spring. Conversely, mobile invertebrates (crabs, sea cucumbers, and urchins) can move to deeper or shallower water and shift their diet source more easily, potentially contributing to the magnitude seasonal variation due to spatial isotopic variation in diet items, inshore versus offshore isotopic gradients, degrees of benthic production, or localized isoscape dynamics (Graham et al. 2010). Although there was isotopic variation in sea otter prey across seasons, seasonal variation in sea otter diet was not attributed to isotopic variation in prey types. These differences across seasons, although not significant at the regional level, could potentially impact isotopic variation at the individual sea otter level. The variability between and within sea otters could also be attributed to metabolic differences of each sea otter, and site differences in the $\delta^{13} \mathrm{C}$ and $\delta^{15} \mathrm{~N}$ values of the prey.

Mean $\delta^{13} \mathrm{C}$ values between seasons exhibited little overall variation around POW. The change in mean $\delta^{13} \mathrm{C}$ values across seasons and sites was $<1 \%$, which is not ecologically significant and is below the confidence intervals of the testing methods used. This shows that at the regional level, sea otters were not making large shifts in diets that varied in their base carbon source (i.e. shifting from majority clams to majority sea urchins). However, there were likely inter-individual differences in dietary composition or foraging location due to sea otters residing outside 

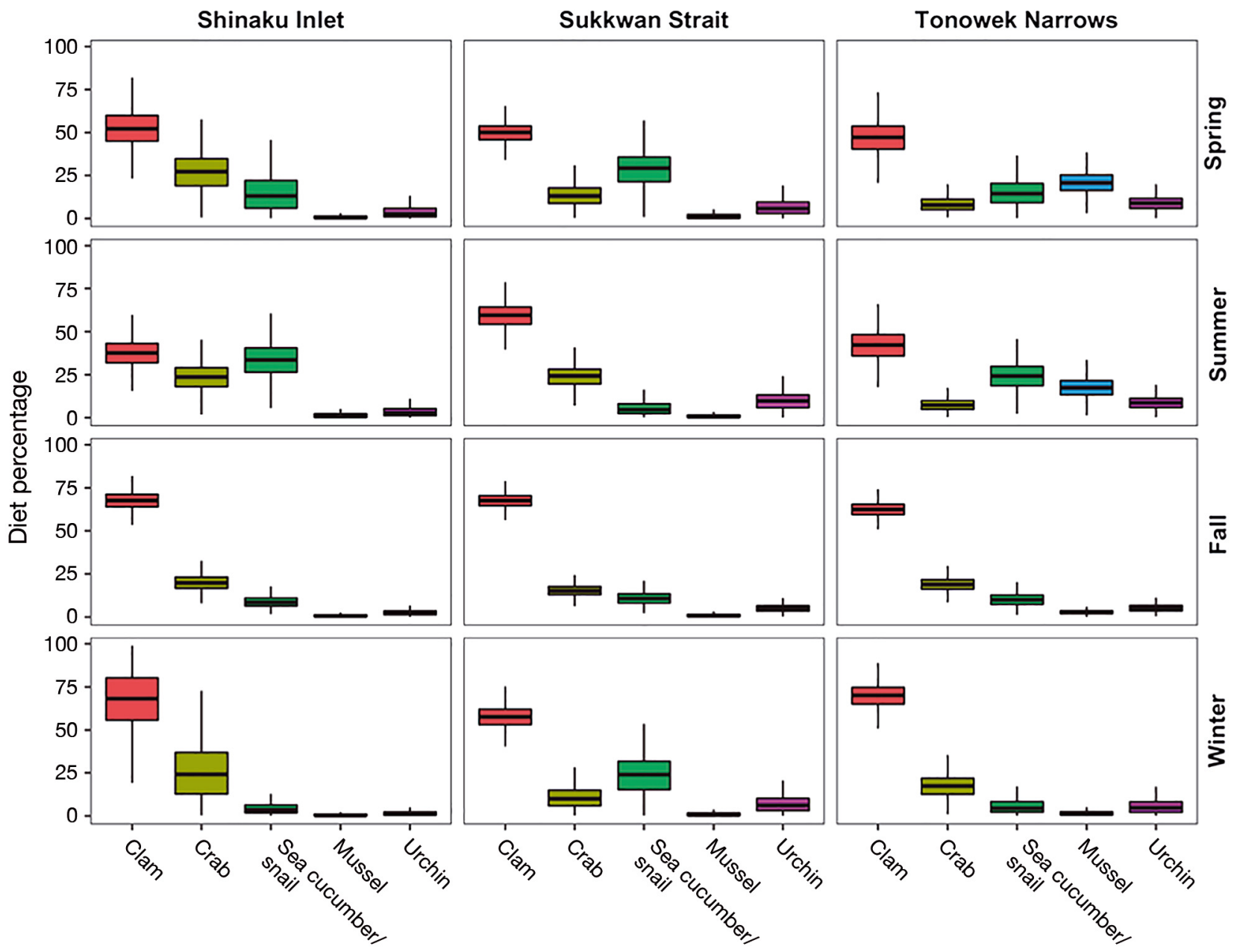

Fig. 6. Sea otter diets estimated by an informed mixing model as a function of harvest location and season for the 5 functional prey groups. Boxes are upper and lower quantiles with a median horizontal line and $95 \%$ credible interval. Models were based on sea otter vibrissae samples from Shinaku Inlet $(n=5)$, Sukkwan Strait $(n=16)$, and Tonowek Narrows $(n=24)$

the $99.5 \%$ confidence interval of the mean seasonal $\delta^{13} \mathrm{C}$ for each site.

Mean $\delta^{15} \mathrm{~N}$ values across seasons and sites had a variation of approximately $1 \%$, less than the $\sim 3 \%$ to signal a trophic level shift (Robinson 2001). This change, similar to that of $\delta^{13} \mathrm{C}$, is likely not ecologically significant because it is approximating the confidence intervals of the testing methods. Therefore, sea otters at a regional level did not exhibit seasonal differences in the overall diet. However, nitrogen exhibited more inter-site variability than carbon. The inter-site and inter-seasonal individual variation that was present could indicate shifts in supplementary diet items (i.e. crabs, sea cucumbers, sea urchins, and snails); this was apparent in the mixing model results that varied by site and season for non-clam diet items.

\subsubsection{Seasonal patterns across harvest sites}

Seasonal effects on sea otter diet varied by sea otter harvest site. Shinaku Inlet had the highest diet uncertainty in the mixing model, which was likely attributed to the low sample size $(\mathrm{n}=5)$ at this site. According to local observations (A. Frisby pers. comm.), Shinaku Inlet is an area with seasonal variation in sea otter presence. This variability could be due in part to the strong hunting pressure in the winter and spring months (B. Benter pers. comm.).

In contrast to Shinaku Inlet, Tonowek Narrows had less uncertainty in diet composition as inferred from stable isotope values. $\delta^{15} \mathrm{~N}$ values were lower in the warmer spring to summer months in comparison to the cooler fall to winter months. Tonowek Narrows is in a region with a high sea otter density that is nearing 
carrying capacity (Tinker et al. 2019). The diet composition of this region, where nitrogen stable isotope signatures show shifts across seasons, could be due in part to high resource competition (Tinker et al. 2012).

Sukkwan Strait is the most recently recolonized site. There was very little regional variation of either $\delta^{13} \mathrm{C}$ or $\delta^{15} \mathrm{~N}$ across all seasons. In previous studies, sea otters in newly recolonized areas have low prey diversity due to more plentiful, energetically rich prey resources (Tinker et al. 2008, Hoyt 2015).

\subsection{Sea otter individuality}

Despite the regional-level specialization on clams throughout POW, there was inter-individual dietary variation that was likely driven by individual sea otter behavior. Across all visual observation sites, there was variability in diet among sea otters, as evidenced by the wide range of prey (33 identified species) recorded. Individual sea otter variation was apparent when looking at the correlation of carbon and nitrogen throughout each vibrissa. Most marine mammal species only have positive correlations of $\delta^{13} \mathrm{C}$ and $\delta^{15} \mathrm{~N}$ along a vibrissa (Cardona et al. 2017, Chilvers 2019). Our study had mostly positive correlations, but $25 \%$ (11/45) of vibrissae had negative correlations, with 2 sea otters exhibiting a significant negative correlation. A negative correlation of values depicts an opposite pattern in the relationship of $\delta^{13} \mathrm{C}$ and $\delta^{15} \mathrm{~N}$ compared to the majority of sea otters, which could signal sea otter movements (e.g. feeding inshore versus offshore) combined with switches in prey; however, the exact reasons are unknown. These unexpected changes in carbon and nitrogen shifts could signal a potential movement to a more pelagically fed system, which, for the southern end of POW where this sea otter was harvested, could mean a confluence of the Gulf of Alaska to the inland island waters, and then feeding at an average higher trophic level. Another possibility is that the sea otter is consuming a higher proportion of gravid, higher trophic level invertebrates (e.g. crabs) during part of the year, such that trophic position increased and an abundance of lipids from the eggs caused declines in $\delta^{13} \mathrm{C}$. Tonowek Narrows had the most positive correlations, with only one negative correlation. Tonowek Narrows represents a regional population at or nearing carrying capacity with a high density of sea otters (Tinker et al. 2019). Sukkwan Strait, the location with significantly negative correlations, is the site with the newest sea otter colonization and a high rate of hunting pressure (T. Peele pers. comm.), both likely pro- moting more sea otter movements (Lafferty \& Tinker 2014, Hoyt 2015).

\subsection{Future work}

Our stable isotope results were similar to our visual foraging results. Thus, future efforts could focus on stable isotopes to document sea otter diets across time and space in regions where visual observations are limited, or in complement to visual foraging studies to elucidate individual sea otter forage patterns. Stable isotopes may be a cost-effective research tool for monitoring sea otter diet changes in the future as they recolonize areas. A limitation of using stable isotope analysis for sea otter diet predictions is the wide range of prey sea otters consume. Because we grouped prey, for example combining sea cucumbers and snails, we were unable to predict diets to as fine of a degree as with visual foraging observations. Future studies could address this issue by using compound-specific isotope analysis to track environmental baselines. We note that all vibrissae for this study were collected during the summer and fall months, which may have led to more accurate estimates of summer and fall isotope values versus winter and spring values due to growth estimation and variation. As the vibrissa grows, the growth rates become more variable depending on factors such as thickness of the keratin and individual growth patterns (Tyrrell et al. 2013, Beltran et al. 2015). Therefore, creating a long-term vibrissae collection library could allow for comparison of $\delta^{13} \mathrm{C}$ and $\delta^{15} \mathrm{~N}$ values from a variety of regions and seasons for future sea otter diet studies. Continued work with harvesters, local tribes, and stakeholders could be an alternative to visual foraging surveys in developing a long-term dietary data set. Continuing diet studies using stable isotopes can provide insight into finescale behavioral differences that may help to explain population-level changes in this nearshore system as sea otters recolonize. The present study, which demonstrated alignment between observational diet studies and vibrissae isotope analyses, along with previous studies of sea otter bone samples (Krylovich 2011, Szpak et al. 2012, Clark et al. 2017, Elliott Smith et al. 2020), allows for the potential to reconstruct past diets from museum and archeological specimens.

\subsection{Conclusions}

Our study revealed no ecologically significant shifts in $\delta^{13} \mathrm{C}$ and $\delta^{15} \mathrm{~N}$ according to season or location, indi- 
cating that sea otters maintained a relatively constant diet overall. However, there was notable individual variation in diet among sea otters, so although clams, a subsistence harvest food for local human communities (Moss 1998), are consumed in high numbers at the regional level, individual sea otters also consumed a wide range of prey. As sea otters return to their historical range, it is likely that sea otters will first have very generalized diets, with individual variation in prey increasing as they reach carrying capacity (Tinker et al. 2008, Hoyt 2015). This study quantified diet estimates for sea otters around POW, which can be incorporated into future models to more effectively account for and project the effects sea otters on commercial and subsistence foods in the Southeast Alaska region.

Acknowledgements. Sea otter vibrissae were collected with help from the US Fish and Wildlife Service sea otter tagging program, specifically Brad Benter and Michelle Kissling, and Algeron Frisby, Theodore Peele, Vaughn Skinna, and the Sea Otter Commission, specifically Dennis Nickerson. We thank Ashley Bolwerk, Maggie Shields, Melanie Borup, Tiffany Stephens, Wendel Raymond, Lia Domke, Sarah Peele, Franz Mueter, Dan Monson, Todd Miller, Emily Fergusson, Corey Fugate, and Robert Bradshaw for field, lab, and analysis assistance. This work was a part of N.L.L.'s Master's thesis at the University of Alaska Fairbanks (UAF). We were funded by the National Science Foundation (NSF) Coastal SEES (Science, Engineering and Education for Sustainability, award no. 1600049), NSF Bio-Oce (Biological Oceanography, award no. 1600230), National Oceanic and Atmospheric Administration, National Marine Fisheries Service, Auke Bay Laboratories (ABL), and Earthwatch Institute. This publication is the result of research sponsored by the Cooperative Institute for Alaska Research with funds from NOAA under cooperative agreement NA13OAR4320056 with the University of Alaska. S.L.K. was supported by BLaST at UAS, which is supported by the NIH Common Fund, through the Office of Strategic Coordination, Office of the NIH Director with the linked awards: TL4GM118992, RL5GM118990, and UL1GM118991. The content is solely the responsibility of the authors and does not necessarily represent the official views of the National Institutes of Health.

Trade names disclaimer. Reference to trade names does not imply endorsement by the National Marine Fisheries Service, NOAA. The perspectives put forward in this paper are those of the authors and not necessarily those of the Department of Commerce or NOAA.

\section{LITERATURE CITED}

Ambrose SH (1990) Preparation and characterization of bone and tooth collagen for isotopic analysis. J Archaeol Sci 17:431-451

Anthony JAM (1995) Habitat utilization by sea otters (Enhydra lutris) in Port Valdez, Prince William Sound, Alaska. MSc thesis, University of Alaska, Fairbanks

Bartoń K (2019) MuMIn: multi-model inference. R package version 1.43.15. https://CRAN.R-project.org/package= MuMIn

*B Bell LE, Bluhm BA, Iken K (2016) Influence of terrestrial organic matter in marine food webs of the Beaufort Sea shelf and slope. Mar Ecol Prog Ser 550:1-24

* Beltran RS, Connolly Sadou M, Condit R, Peterson SH, Reichmuth C, Costa DP (2015) Fine-scale whisker growth measurements can reveal temporal foraging patterns from stable isotope signatures. Mar Ecol Prog Ser 523: 243-253

Beltran RS, Peterson SH, McHuron EA, Reichmuth C, Hückstädt LA, Costa DP (2016) Seals and sea lions are what they eat, plus what? Determination of trophic discrimination factors for seven pinniped species. Rapid Commun Mass Spectrom 30:1115-1122

Brown KL, Atkinson S, Keller KB, Pearson HC (2019) Diet of northern sea otters (Enhydra lutris kenyoni) from Icy Strait, Alaska, based on stomach contents analysis. Mar Mamm Sci 35:637-640

Burris OE, McKnight DE (1973) Game transplants in Alaska. Game Technical Bulletin No 4. Alaska Department of Fish and Game, Juneau, AK

Calkins DG (1978) Feeding behavior and major prey species of the sea otter, Enhydra lutris, in Montague Strait, Prince William Sound, Alaska. Fish Bull 76:125-131

Cardona L, Vales D, Aguilar A, Crespo E, Zenteno L (2017) Temporal variability in stable isotope ratios of $\mathrm{C}$ and $\mathrm{N}$ in the vibrissa of captive and wild adult South American sea lions Otaria byronia: more than just diet shifts. Mar Mamm Sci 33:975-990

Cartagena da Silva Matos B (2016) Do sea otters forage according to prey's nutritional value? MSc thesis, Universidade de Aveiro Departamento de Biologia, Aveiro, Portugal

* Caut S, Angulo E, Courchamp F (2009) Variation in discrimination factors $\left(\Delta^{15} \mathrm{~N}\right.$ and $\left.\Delta^{13} \mathrm{C}\right)$ : the effect of diet isotopic values and applications for diet reconstruction. J Appl Ecol 46:443-453

Chilvers B (2019) Whisker stable isotope values indicate long-term foraging strategies for female New Zealand sea lions. Endang Species Res 38:55-66

Clark CT, Horstmann L, Misarti N (2017) Quantifying variability in stable carbon and nitrogen isotope ratios within the skeletons of marine mammals of the suborder Caniformia. J Archaeol Sci Rep 15:393-400

Coletti HA, Dean TA, Kloecker KA, Ballachey BE (2014) Nearshore marine vital signs monitoring in the Southwest Alaska Network of National Parks: 2012. Natural Resource Technical Report NPS/SWAN/NRTR-2014/ 843. National Park Service, Fort Collins, CO

Costa DP (1982) Energy, nitrogen, and electrolyte flux and sea water drinking in the sea otter Enhydra lutris. Physiol Zool 55:35-44

Crawford K, Mcdonald RA, Bearhop S (2008) Applications of stable isotope techniques to the ecology of mammals. Mammal Rev 38:87-107

Davis RW (2020) Marine mammals: adaptations for an aquatic life, 1st edn. Springer Nature Switzerland, Cham

Dean TA, Bodkin JL, Fukuyama AK, Jewett SC, Monson DH, O'Clair CE, VanBlaricom GR (2002) Food limitation and the recovery of sea otters following the 'Exxon Valdez' oil spill. Mar Ecol Prog Ser 241:255-270

Elliott Smith EA, Newsome SD, Estes JA, Tinker MT (2015) The cost of reproduction: differential resource specialization in female and male California sea otters. Oecologia 178:17-29 
Elliott Smith EA, Tinker MT, Whistler EL, Kennett DJ and others (2020) Reductions in the dietary niche of southern sea otters (Enhydra lutris nereis) from the Holocene to the Anthropocene. Ecol Evol 10:3318-3329

Estes JA, Duggins DO (1995) Sea otters and kelp forests in Alaska: generality and variation in a community ecological paradigm. Ecol Monogr 65:75-100

Estes JA, Palmisano JF (1974) Sea otters: their role in structuring nearshore communities. Science 185:1058-1060

* Estes JA, Riedman ML, Staedler MM, Tinker MT, Lyon BE (2003) Individual variation in prey selection by sea otters: patterns, causes and implications. J Anim Ecol 72: 144-155

Estes JA, Heithaus M, McCauley DJ, Rasher DB, Worm B (2016) Megafaunal impacts on structure and function of ocean ecosystems. Annu Rev Environ Resour 41:83-116

Fry B (2006) Stable isotope ecology. Springer, New York, NY

*Graham BS, Koch PL, Newsome SD, McMahon KW, Aurioles D (2010) Using isoscapes to trace the movements and foraging behavior of top predators in oceanic ecosystems. In: West JB, Bowen GJ, Dawson TE, Tu KP (eds) Isoscapes: understanding movement, pattern, and process on Earth through isotope mapping. Springer, Dordrecht, p 299-318

Hale JR, Laidre KL, Tinker MT, Jameson RJ, Jeffries SJ, Larson SE, Bodkin JL (2019) Influence of occupation history and habitat on Washington sea otter diet. Mar Mamm Sci 35:1369-1395

Hoyt ZN (2015) Resource competition, space use and forage ecology of sea otters, Enhydra lutris, in southern Southeast Alaska. PhD dissertation, University of Alaska, Fairbanks, AK

Hughes BB, Eby R, Van Dyke E, Tinker MT, Marks CI, Johnson KS, Wasson K (2013) Recovery of a top predator mediates negative eutrophic effects on seagrass. Proc Natl Acad Sci USA 110:15313-15318

Jameson RJ, Kenyon KW, Johnson AM, Wight HM (1982) History and status of translocated sea otter populations in North America. Wildl Soc Bull 10:100-107

Krylovich OA (2011) Hunting impacts on the sea otter (Enhydra lutris) population in Clam Lagoon (Adak Island, Aleutian Islands) 7,000 years ago? Results of preliminary stable isotope analysis. J Island Coast Archaeol 6:155-159

Kvitek RG, Bowlby CE, Staedler M (1993) Diet and foraging behavior of sea otters in Southeast Alaska. Mar Mamm Sci 9:168-181

Lafferty KD, Tinker MT (2014) Sea otters are recolonizing southern California in fits and starts. Ecosphere 5:1-11

LaRoche NL (2020) Sea otter diet composition with respect to recolonization, life history, and season in southern Southeast Alaska. MSc thesis, University of Alaska Fairbanks, AK

LaRoche NL, Rogers MC (2020) Sea otter foraging analysis using stable isotopes. Knowledge Network for Biocomplexity, doi:10.5063/F1FJ2F6T

LaRoche NL, King SL, Pearson HC (2020) Sea otter foraging data, visual observations from Prince of Wales, Alaska. Knowledge Network for Biocomplexity, doi:10.5063/F1C 53J8X

Larson SD, Hoyt ZN, Eckert GL, Gill VA (2013) Impacts of sea otter (Enhydra lutris) predation on commercially important sea cucumbers (Parastichopus californicus) in Southeast Alaska. Can J Fish Aquat Sci 70:1498-1507

Lenth R (2019) emmeans: estimated marginal means, aka least-squares means. R package version 1.4.2. https:// CRAN.R-project.org/package=emmeans

Lesage V, Hammill MO, Kovacs KM (2002) Diet-tissue fractionation of stable carbon and nitrogen isotopes in phocid seals. Mar Mamm Sci 18:182-193

Mandi DA (2020) Trophic ecology of northern sea otter (Enhydra lutris) in southcentral and southwest Alaska utilizing stable isotope ratios. Capstone. Nova Southeastern University, Fort Lauderdale, FL

Marine Mammal Commission (2018) The Marine Mammal Protection Act of 1972. NOAA National Marine Fisheries Service, Bethesda, MD

Moss ML (1998) Northern northwest coast regional overview. Arctic Anthropol 35:88-111

Newsome SD, Tinker MT, Monson DH, Oftedal OT and others (2009) Using stable isotopes to investigate individual diet specialization in California sea otters (Enhydra lutris nereis). Ecology 90:961-974

Newsome SD, Clementz MT, Koch PL (2010) Using stable isotope biogeochemistry to study marine mammal ecology. Mar Mamm Sci 26:509-572

*Newsome SD, Tinker MT, Gill VA, Hoyt ZN, Doroff A, Nichol L, Bodkin JL (2015) The interaction of intraspecific competition and habitat on individual diet specialization: a near range-wide examination of sea otters. Oecologia 178:45-59

Oftedal OT, Ralls K, Tinker MT, Green A (2007) Nutritional constraints on the southern sea otter in the Monterey Bay National Marine Sanctuary. Joint Final Report to Monterey Bay National Marine Sanctuary (and Monterey Bay Sanctuary Foundation) and the Marine Mammal Commission. Monterey Bay National Marine Sanctuary, Monterey, CA

Pinheiro J, Bates D, DebRoy S, Sarkar D, R Core Team (2020) nlme: linear and nonlinear mixed effects models. R package version 3.1-145. https://CRAN.R-project.org/ package $=$ nlme

*Post DM (2002) Using stable isotopes to estimate trophic position: models, methods, and assumptions. Ecology 83: 703-718

* Post DM, Layman CA, Arrington DA, Takimoto G, Quattrochi J, Montaña CG (2007) Getting to the fat of the matter: models, methods and assumptions for dealing with lipids in stable isotope analyses. Oecologia 152:179-189

Pritchett M, Hoyt ZN (2008) Report to the Board of Fisheries, miscellaneous dive fisheries. Fishery Management Report No 08-63. Alaska Department of Fish and Game, Anchorage, AK

R Core Team (2020) R: a language and environment for statistical computing. R Foundation for Statistical Computing, Vienna

Raymond WW, Hughes BB, Stephens TA, Mattson CR, Bolwerk AT, Eckert GL (2021) Testing the generality of sea otter-mediated trophic cascades in seagrass meadows. Oikos 130:725-738

* Rechsteiner EU, Watson JC, Tinker MT, Nichol LM and others (2019) Sex and occupation time influence niche space of a recovering keystone predator. Ecol Evol 9: 3321-3334

* Robinson D (2001) $\delta^{15} \mathrm{~N}$ as an integrator of the nitrogen cycle. Trends Ecol Evol 16:153-162

Sponheimer M, Robinson T, Ayliffe L, Hammer J and others (2003) Nitrogen isotopes in mammalian herbivores: hair $\delta^{15} \mathrm{~N}$ values from a controlled feeding study. Int $\mathrm{J}$ Osteoarchaeol 13:80-87 
Stock BC, Semmens BX (2016) MixSIAR GUI User Manual. Version 3.1. https://github.com/brianstock/MixSIAR

Szpak P, Orchard TJ, McKechnie I, Grocke DR (2012) Historical ecology of late Holocene sea otters (Enhydra lutris) from northern British Columbia: isotopic and zooarchaeological perspectives. J Archaeol Sci 39:1553-1571

Tinker MT, Bentall G, Estes JA (2008) Food limitation leads to behavioral diversification and dietary specialization in sea otters. Proc Natl Acad Sci USA 105:560-565

Tinker MT, Guimarães PR, Novak M, Marquitti FMD and others (2012) Structure and mechanism of diet specialisation: testing models of individual variation in resource use with sea otters. Ecol Lett 15:475-483

Tinker MT, Gill VA, Esslinger GG, Bodkin J and others (2019) Trends and carrying capacity of sea otters in Southeast Alaska. J Wildl Manag 83:1073-1089

Editorial responsibility: Lisa Ballance,

Newport, Oregon, USA

Reviewed by: L. Elizabeth Drake and 2 anonymous referees
Tyrrell LP, Newsome SD, Fogel ML, Viens M, Bowden R, Murray MJ (2013) Vibrissae growth rates and trophic discrimination factors in captive southern sea otters (Enhydra lutris nereis). J Mammal 94: 331-338

Weitzman BP (2013) Effects of sea otter colonization on softsediment intertidal prey assemblages in Glacier Bay, Alaska. MA thesis, University of California, Santa Cruz, CA

Wild LA, Mueter F, Witteveen B, Straley JM (2020) Exploring variability in the diet of depredating sperm whales in the Gulf of Alaska through stable isotope analysis. R Soc Open Sci 7:191110

Wolf N, Carleton SA, Martínez del Rio C (2009) Ten years of experimental animal isotopic ecology. Funct Ecol 23: $17-26$

Submitted: March 16, 2021

Accepted: August 17, 2021

Proofs received from author(s): October 21, 2021 